\title{
Corpusurile paralele. $O$ modalitate de cercetare în timp real a schimbării lingvistice în curs de realizare
}

\author{
Christian Mair* \\ Departamentul de Anglistică, Universitatea „Albert Ludwig” din Freiburg, Rempartstr. 15, DE-79098 Freiburg, Germania
}

\begin{tabular}{|c|c|}
\hline Despre articol & Rezumat \\
\hline $\begin{array}{l}\text { Istoric: } \\
\text { Primit } 3 \text { iunie } 2014 \\
\text { Acceptat } 12 \text { iunie } 2014 \\
\text { Publicat } 13 \text { ianuarie } 2015 \\
\text { Cuvinte-cheie: } \\
\text { lingvistica corpusului } \\
\text { schimbare lingvistică } \\
\text { limba engleză contemporană } \\
\text { corpusuri paralele } \\
\text { informalitate }\end{array}$ & $\begin{array}{l}\text { Lucrarea valorifică date din patru corpusuri corespondente de cîte un milion } \\
\text { de cuvinte, Brown (Engleză americană, 1961), LOB (Engleză britanică, 1961), } \\
\text { Frown (Engleză americană, 1992) și FLOB (Engleză britanică, 1991) pentru a } \\
\text { oferi o descriere integrată a variației sincronice (regionale și stilistice) și a schim- } \\
\text { bărilor diacronice pe termen scurt din engleza literară scrisă. Analiza unui nu- } \\
\text { măr relativ mare de variabile morfosintactice arată că schimbările structurale } \\
\text { directe sînt mai degrabă rare în perioada avută în vedere. Cu toate acestea, există } \\
\text { numeroase evoluții diacronice semnificative sub aspect statistic care, conside- } \\
\text { rate împreună, oferă dovezi ce atestă o tendință discursiv-pragmatică unitară, și } \\
\text { anume, „colocvializarea” normelor limbii engleze scrise. Se consideră că această } \\
\text { evoluție lingvistică este motivată de un curent socio-cultural mai larg, deplasarea } \\
\text { gustului public către o exprimare informală din ce în ce mai pregnantă. }\end{array}$ \\
\hline
\end{tabular}

\section{Introducere}

Gradul de interes public (și numărul de studii) privind schimbarea lingvistică în limba engleză contemporană se află în raport de inversă proporționalitate cu fiabilitatea principalelor metode întrebuințate în cercetarea fenomenului, mai precis observațiile de conjunctură ale observatorilor, călătorilor și expatriaţilor. Această stare de fapt contrastează pregnant cu studiile asupra limbii engleze vechi și medievale, invariabil axate pe cercetarea mai mult sau mai puțin sistematică a unor segmente ale corpusului existent de texte scrise. Lucrarea de față este o încercare de a adapta, în studiul schimbărilor actuale, metodele folosite pe scară largă în analiza pe bază de corpus a stadiilor anterioare de limbă engleză. În acest demers, împărtăşesc optimismul lui Janet Holmes, care afirmă că:

„Perspectiva de a folosi informațiile de ordin cantitativ pentru a evalua manifestarea în timp a schimbării lingvistice este captivantă. În mod cert este posibilă realizarea de comparații sugestive și interesante între frecvențele elementelor din corpusuri de mărimi și alcătuiri similare, realizate în momente diferite." (Holmes, 1994, p. 37).

Tipul „clasic” de analiză avut în vedere constă în compararea corespondențelor lingvistice între traducerile succesive ale Bibliei. Deoarece corpusul biblic este constant ca mărime și compoziție, prezența unor forme noi sau a unor mutații în distribuția variantelor fie se datorează hazardului, fie este o reflectare nemijlocită a inovației și evoluției lingvistice. Jespersen ne oferă una din numeroasele ilustrări ale metodei în cauză:

„Măsura în care limba se schimbă sub acest aspect poate fi reliefată de comparația pe care i-am sugerat-o unuia dintre elevii mei, și anume de a verifica corespondențele între Evanghelia Sf. Marcu din Versiunea Autorizatăa și versiunea din secolul al XX-lea: în 28 de cazuri, în ambele

*Adresă de corespondență: christian.mair@anglistik.uni-freiburg.de.

${ }^{a}$ Biblia Regelui Iacob I (King James Bible, 1611) (n.tr.) 
versiuni au fost identificate timpuri dezvoltate ${ }^{b}$, însă, în 78 de cazuri, în versiunea nouă figurau timpuri dezvoltate, în vreme ce în Versiunea Autorizată erau timpuri simple, și doar într-un singur caz în Versiunea Autorizată exista un timp dezvoltat, iar în versiunea nouă, un timp simplu." (Jespersen, 1909-1949, IV, p. 177).

Traducerile aceluiași text, dar din perioade diferite, constituie cazuri rare și fericite de corpusuri corespondente. Proiecte precum ARCHER (corpus istoric reprezentativ de registre ale limbii engleze, vezi Biber et al., 1994) și Corpusul Helsinki demonstrează că este posibilă obținerea de rezultate, deși corespondența este delimitată mai cuprinzător, cum ar fi, de pildă, prezența unui volum comparabil de material lingvistic din texte de acelaşi fel sau de tip asemănător.

Cercetarea limbii engleze moderne cu mijloacele lingvisticii corpusului s-a dezvoltat mai cu seamă la începutul anilor 1960, prin compilarea corpusurilor Brown și $\mathrm{LOB}^{\mathrm{c}}$, acestea fiind eșantioane de corespondențe privind limba literară scrisă în Statele Unite ale Americii și în Marea Britanie. Aceste baze de date au în prezent o vîrstă apreciabilă. Pentru a le menține utilitatea, a fost necesară alcătuirea unor replicitemporar cunoscute sub denumiri ca Frown și FLOB ${ }^{1}$ — cu aceleași dimensiuni și alcătuiri, dar cu material textual din anii 1991 și 1992, nu din 1961, ca în corpusurile originale.

Ansamblul celor patru corpusuri corespondente aflate la dispoziția cercetătorilor a permis:

i) testarea unora din ipotezele actuale privind schimbarea lingvistică în limba engleză contemporană;

ii) identificarea unor schimbări nediscutate în literatura de specialitate, prin compararea sistematică a frecvențelor lexicale, în special pe cele ale elementelor din clase închise;

iii) abordarea sistematică a unuia dintre aspectele metodologice majore în cercetarea schimbării în curs de realizare, și anume inter-dependența variației regionale (în cazul de faţă britanică vs. americană) și stilistice sincronice, pe de o parte, și evoluțiile diacronice, pe de altă parte.

În acest cadru, este oportun un comentariu asupra utilităţii corpusurilor. Aceste instrumente nu îl pot călăuzi pe utilizator către identificarea originii unei inovații. Cele mai multe schimbări fonetice și morfosintactice își au izvorul probabil în vorbire, după care se răspîndesc în scris, și nu rezultă nimic din faptul că o atestare anterioară a 'ceva nou' este, din întîmplare, prezentă și în Frown sau FLOB, chiar dacă avem de-a face cu inovații de factură scrisă. Acest aspect este subliniat de Lass (1980, p. 95) în concordanță cu Bloomfield (1933, p. 347 ș.u.):

„În ultimă instanță, nu poate fi surprins cu exactitate momentul în care o schimbare începe să se realizeze (poate din pură întîmplare, și nici atunci nu am putea ști cu siguranță ce anume observăm)",

iar acest aspect este a fortiori adevărat pentru demersul de faţă, întemeiat în mod exclusiv pe fapte de limbă scrisă.

Așadar, interesul principal al lucrării nu este legat de momentul de apariție, ci de răspîndirea unui element novator, înregistrat ca mutaţie în raport cu diacronia ipostazelor formale.

E de la sine înțeles că datele cuprinse în corpusurile de limbă scrisă nu sînt de folos în cercetarea schimbărilor sonore. Mai mult decît atît, corpusuri precum FLOB și Frown sînt prea mici pentru a permite

\footnotetext{
b̂̂n concepția lui Jespersen, un timp dezvoltat este o structură verbală complexă, de tip sintetic sau analitic, formată pe baza unei forme verbale simple. Astfel, în limba engleză, un timp simplu precum prezentul indicativului: You write, intră în opoziție cu timpuri dezvoltate precum aspectul continuu al aceluiași timp: You are writing, ori cu forme analitice cum ar fi trecutul emfatic: He did sing sau viitorul anterior: He shall have been singing (n.tr.).

${ }^{\mathrm{c} C}$ Corpusul LOB [Lancaster-Oslo/Bergen] este o bază de date lingvistice de aproximativ un milion de cuvinte, compilată prin colaborarea specialiștilor de la universitățile din Lancaster (Marea Britanie), Oslo și Bergen (Norvergia), ca reacție față de apariția corpusului BROWN [Brown University Standard Corpus of Present-Day American English], alcătuit de Henry Kucera și W. Nelson Francis. Proporționale ca mărime și ca diversitate textuală, cele două corpusuri pun față în față eșantioane de text scris din engleza americană (BROWN) și britanică (LOB) (n.tr.).

${ }^{1}$ Frown, de la „Freiburg version of Brown Corpus” [Varianta de la Freiburg a corpusului Brown]; FLOB, de la „Freiburg version of the LOB corpus" [Varianta de la Freiburg a corpusului LOB] (indicațiile între paranteze pătrate aparțin traducătorului). Cititorul este rugat să ierte jocurile de cuvinte involuntare.
} 
investigarea neologismelor și a majorității procedeelor lexical-formative. De aceea, schimbările gramaticale, mai ales cele din categoria fenomenelor cu frecvență ridicată de uz, constituie aria de cercetare cea mai promițătoare.

\section{Cercetări anterioare asupra schimbării gramaticale în engleza contemporană}

Studiile notabile dedicate problemei sînt trei monografii, din care două (Barber, 1964 și Potter, 1969) prezintă rezultate documentate ale unor observații individuale, în timp ce Bauer (1994) oferă prima investigație în care se adoptă o perspectivă întemeiată pe analiza la scară foarte mică a datelor dintr-un corpus. Dacă se ia în considerare că baza de date folosită este alcătuită din texte dintr-un singur gen (editoriale publicate în cotidianul Times între 1900 și 1985) și nu depășește 200.000 de cuvinte care evidenţiază optsprezece stadii succesive de limbă dintre 1900 și 1985, rezultatele sînt neconcludente.

În limba engleză literară actuală par a se produce următoarele schimbări de tip gramatical:

a) regularizarea analogică a formelor neregulate de plural ale substantivelor și a formelor verbale de trecut şi de participiu trecut,

b) suspendarea opozițiilor de caz ale pronumelor [de exemplu, he (el)/ him (lui)] și pierderea lui whom (cui),

c) creșterea frecvenței substantivelor inanimate cu forme de genitiv sintetic (engl. s-genitive - n.tr.),

d) descreșterea frecvenței comparativului cu flectiv în cazul adjectivelor disilabice și, într-o anumită măsură, chiar a celor monosilabice,

e) creșterea frecvenței viitorului continuu și a celui de tip going-to; noi întrebuințări ale viitorului continuu în structuri verbale ce exprimă starea,

f) formele de trecut simplu care le uzurpă pe cele de mai mult ca perfect și de prezent perfect,

g) schimbările din sistemele de verbe modale și auxiliare (de pildă, dispariția lui shall din forma de viitor, marginalizarea lui ought to, regularizarea verbelor have, need, dare și used to în interogații și negații, gramaticalizarea formelor wanna și gotta, înlocuirea lui might cu may în anumite contexte),

h) creșterea numărului și frecvenței de uz ale verbelor frazale,

i) seria de schimbări parțial conflictuale ale acordului dintre verb și substantiv (precum toleranța crescută față de folosirea pronumelui de plural they ca „singular” și toleranța redusă față de întrebuințarea formelor verbale de plural acordate cu substantive colective-cf. the government are...),

j) revitalizarea subjonctivului în exprimarea formală.

Față de aceste tendințe, mai există o serie de schimbări lexico-gramaticale care afectează de obicei doar elemente lexicale individuale și care, în mod normal, se produc datorită schimbărilor de sens, acestea afectînd cadrele sintactice de ocurență ale cuvintelor respective (de ex. that's a nonsense, discutat de Greenbaum, 1986, p. 6-7), reanalizei ${ }^{\mathrm{d}}$ (due to), conversiunii (folosirea lui like drept conjuncție) sau gramaticalizării progresive (întrebuințările cvasi-prepoziționale ale participiului following, cf. Olofsson, 1990). Astfel de fenomene tind să treacă neobservate dacă nu cumva trezesc mînia prescriptiviștilor, caz în care importanța lor este mult exagerată, aşa cum s-a întîmplat în cruciada iscată de hopefully (cf. Greenbaum, 1988, p. 11).

În cele ce urmează, voi prezenta succint cîteva din rezultatele deja obţinute prin demersuri cantitative solide (Secțiunea 3). Cu toate acestea, cea mai fructuoasă arie de cercetare rămîne aceea în care testarea anumitor ipoteze formulate în literatura de specialitate se sprijină pe statistici relativ modeste, aşa cum se întîmplă, de exemplu, în studiile teoretice privind gramaticalizarea. Beneficiile cooperării între lingviștii interesați de corpusuri și cei preocupați de teorie sînt evidente. Lingviștii interesați de corpusuri își văd liniștiți de ale lor, cu o oarecare doză de ingenuitate, adăugînd cu entuziasm noi seturi de date cantitative la cele deja existente și fără a se preocupa prea mult de însemnătatea în plan mai cuprinzător a descoperirilor

\footnotetext{
${ }^{\mathrm{d}}$ Engl. reanalysis. În lucrarea $A$ Dictionary of Linguistics and Phonetics, ediția a șasea, 2008, Blackwell, p. 403, David Crystal definește termenul drept „schimbare care afectează structura sau funcția unei forme lingvistice. De exemplu, cînd două cuvinte se contopesc sau se compun, identitatea fiecărui constituent este reanalizată ca întreg (hair, substantiv $+c u t$, verb $=$ haircut, substantiv)" (n.tr.).
} 
pe care le fac. Pe de altă parte, studiul teoretic al gramaticalizării operează cu un număr limitat de exemple consacrate (cum ar fi gramaticalizarea verbului go și a verbelor ce funcționează ca mărci ale viitorului în diverse alte limbi), dar întîmpină dificultăți serioase de ilustrare de îndată ce atenția se axează asupra unor fenomene mai recente. De aceea este indicat ca cele două perspective să fie corelate pentru ca fiecare să-și întărească exact părțile mai slabe. Acest aspect va fi explorat și discutat în Secțiunea 4.

În Secțiunea 5 va fi argumentat că schimbările cele mai pronunțate în uzul formelor gramaticale nu sînt direct legate de inovația de tip gramatical. Mai degrabă, ele reflectă o colocvializare a limbii engleze scrise, adică o schimbare a convențiilor stilistice provocată de curentul informalității și (pseudo-)democratizării care afectează societăţile capitaliste dezvoltate (cf. Hobsbawm, 1994; Featherstone, 1991; Elias, 1989).

\section{Schimbări gramaticale în limba engleză: cîteva evoluții semnificative din punct de vedere statistic}

Mair \& Hundt (1995) au demonstrat că nu există ${ }^{2}$ deosebiri statistice semnificative în privința formelor de aspect continuu din textele secțiunilor de publicistică din corpusurile Brown și LOB. Cu alte cuvinte, corpusurile nu prezintă evidențe care să reflecte diferențe regionale în întrebuințarea aspectului continuu în engleza americană și britanică. Există, totuși, deosebiri „foarte semnificative” și „semnificative” între LOB și FLOB și între Brown și Frown. Acest fapt dovedește că uzul aspectului continuu s-a schimbat în ultimii treizeci de ani. Cele mai interesante date sînt următoarele:

\begin{tabular}{lllll}
\hline & Brown $A-C$ & Frown $A-C$ & LOB A-C & FLOB A-C \\
\hline prezent continuu & 349 & 408 & 340 & 408 \\
aspect continuu (total) & 593 & 663 & 606 & 715 \\
\hline
\end{tabular}

Tabela 1: Formele de aspect continuu în patru corpusuri.

Deosebirile între Brown și Frown sînt „semnificative”, iar cele dintre Lob și FLOB sînt „foarte semnificative”. În analiza calitativă detaliată a materialului nu au fost identificate cauze gramaticale pentru creșterea observată. Întrebuințări pretins noi precum verbe de stare sau structuri cu aspect continuu, de tipul „it + is being expletiv" (de exemplu, it was being the afternoon of a lifetime ${ }^{\mathrm{e}}$ ) fie erau deja prezente în materialul vechi, fie nu au fost atestate în cel nou. În orice caz, astfel de întrebuințări sînt atît de rare încît nu influențează deloc statistica. Astfel, singura motivație a creșterii este că, în prezent, aspectul continuu este mai des folosit în situațiile în care alegerea între formele aspectuale simple și continue există de mai multă vreme. Întrucît în asemenea cazuri aspectul continuu este în mod obișnuit considerat o opțiune stilistică de tip informal, problema va fi dezbătută în secțiunea a cincea.

Același studiu a relevat că viitorul de tip going-to a devenit mai frecvent (Mair \& Hundt, 1995, p. 114):

\begin{tabular}{lllll}
\hline & Brown $A-C$ & Frown $A-C$ & LOB A-C & FLOB A-C \\
\hline viitorul de tip going-to în vorbirea directă & 7 & 51 & 9 & 19 \\
viitorul de tip going-to (total) & $\mathbf{3 0}$ & $\mathbf{6 7}$ & $\mathbf{3 0}$ & $\mathbf{4 6}$ \\
\hline
\end{tabular}

Tabela 2: Formele de viitor going-to în patru corpusuri.

Frecvența mai mare a formelor în materialul nou nu se datorează prezenței de întrebuințări noi. Din nou, cea mai plauzibilă explicație a creșterii este că respectiva opțiune stilistică informală se folosește mai frecvent în scris decît în urmă cu treizeci de ani.

\footnotetext{
${ }^{2} \mathrm{Ca}$ singură excepție este viitorul continuu, mai frecvent în materialul lingvistic britanic, cu indicele de semnificație „„” (= „semnificativ”, spre deosebire de „b - foarte semnificativ” și „a - cel mai semnificativ”, cf. Mair \& Hundt, 1995, p. 120-121).

${ }^{\mathrm{e}} \mathrm{A}$ fost după-amiaza vieții (n.tr.).
} 
În două dintre cele mai laborioase studii întreprinse pinnă acum asupra materialului, Siemund (1993) și Raab-Fischer (1995) au stabilit că frecvența genitivului flexionar a crescut în aproximativ aceeași măsură în care structurile genitivale cu of au devenit mai rare. Am sintetizat tabelul de mai jos pe baza studiilor menționate, furnizînd raportul 's/of pentru șapte categorii de substantive:

\begin{tabular}{lcc}
\hline & $L O B A-C$ & $F L O B A-C$ \\
\hline nume de persoană & $443: 178$ & $692: 170$ \\
substantive personale & $259: 483$ & $245: 360$ \\
substantive colective & $175: 528$ & $311: 381$ \\
animale superioare & $5: 8$ & $9: 9$ \\
substantive locative/geografice & $159: 478$ & $286: 331$ \\
substantive temporale & $80: 149$ & $120: 144$ \\
alte substantive & $38: 2059$ & $79: 1984$ \\
substantive (total) & $\mathbf{1 1 5 9 : 3 8 8 3}$ & $\mathbf{1 7 4 2 : 3 3 7 9}$ \\
\hline
\end{tabular}

Tabela 3: Formele genitivale sintetice (cu ss) vs. analitice (cu of) în șapte categorii de substantive.

Ne aflăm iarăşi în fața unei situații familiare: a crescut considerabil un presupus „uz” nou, genitivul sintetic (cu 's) al categoriei 'alte substantive', dar cea mai mare parte a fluctuației reflectă o schimbare de preferințe în zone în care variația exista deja de mult timp. Par a fi implicați factori stilistici, însă ei sînt mai puțin clar legați de dimensiunea vorbit/scris decît în cazul viitorului de tip going-to.

Un ultim exemplu care ilustrează influența evidentă a limbii engleze vorbite asupra celei scrise este toleranța crescută în scris față de contrageri. Dintre datele multiple oferite de Krug (1994), cele mai semnificative sînt ocurențele structurii it's:

\begin{tabular}{llcll}
\hline & $L O B A-C$ & $F L O B A-C$ & Brown $A-C$ & Frown $A-C$ \\
\hline în citate & 15 & 44 & 13 & 90 \\
în titluri & 1 & 8 & 4 & 11 \\
în textul normal & 7 & 48 & 30 & 112 \\
total & $\mathbf{2 3 ( 4 7 9 )}$ & $\mathbf{1 0 0 ( 3 4 5 )}$ & $\mathbf{4 7}(\mathbf{2 6 7})$ & $\mathbf{2 1 3 ( 1 6 0 )}$ \\
\hline
\end{tabular}

Tabela 4: Uzul construcției it’s în patru corpusuri.

Numerele între paranteze rotunde oglindesc formele necontrase. Rezultatele arată că nu au fost încă atinși coeficienții de contragere din engleza vorbită, deși în ultimii treizeci de ani s-a făcut un salt uriaș în această direcție, mai ales în engleza americană, în care forma contrasă it's constituie deja norma, statistic vorbind.

\section{Schimbări gramaticale în limba engleză: gramaticalizarea incipientă}

Spre deosebire de fenomenele de mare frecvență discutate în secțiunea anterioară, datele prezentate în această secțiune sînt sugestive, dar nu concludente. Totuși, e bine să ne amintim că relația dintre semnificația statistică și cea lingvistică este complexă: în corpusuri există parametri relevanți sub aspect statistic, dar care nu pot fi interpretați din perspectivă lingvistică, după cum anumite fapte semnificative sub aspect lingvistic nu au impact statistic.

Teoria gramaticalizării, adică studiul manierei în care morfemele gramaticale se constituie din lexic, este unul din domeniile cu cea mai mare dezvoltare în teoria lingvistică modernă (vezi Mair, 1994 pentru referințe bibliografice). Ceea ce mi-a permis să unesc studiul lingvistic al corpusurilor cu teoria gramaticalizării ține de afirmațiile frecvent formulate de teoreticienii gramaticalizării, conform cărora metodele specifice cu randament bun în cercetarea istoriei lingvistice îndepărtate nu au dat roade în analiza schimbărilor în curs de realizare. Iată, spre exemplu, o asemenea afirmaţie: 
„Die früheste Phase der Grammatikalisierung-also die Entstehung von Formeln und einfachen 'pattern'-aktuell zu verfolgen, ist phänomenologisch unmöglich. Ungeheure Massen an Diskursen mit einem potentiell grammatikalisierenden Kandidaten müßten aufgezeichnet und, vor allem ausgewertet, werden, doch nach welchen Kriterien? Und welche sind die Kandidaten?" (Compes et al., 1993, p. 20)

[Cercetarea primei faze de gramaticalizare, adică apariția formulelor și tiparelor simple este o imposibilitate fenomenologică. O masă discursivă imensă în care să existe potențiale elemente de gramaticalizare ar trebui parcusă și, mai cu seamă, evaluată. Dar în acord cu ce criterii? Și care sînt elementele?]

„Studiul schimbării de natură gramaticală pe baza datelor evidențiate de variația sincronică (sau, cel mai bine, brahicronică) din stadiul actual al unei limbi rămîne o problemă serioasă de analizat. Date fiind mijloacele metodologice aflate în prezent la dispoziția cercetătorilor, este aproape imposibil de știut care dintre schimbările prezente în vorbire sînt manifestări sincronice ale unei autentice schimbări de limbă în curs de realizare și care sînt mode efemere." (Lehmann, 1991, p. 532)

Acest scepticism este nefondat în era lingvisticii cantitative. Nu există deja volumul de material discursiv solicitat de Compes et al. (1993) sub formă de ziare în format digital, acumulate masiv de la an de an? Nu sînt corpusurile LOB/FLOB și Brown/Frown „mijloacele metodologice aflate în prezent la dispoziție” pentru a clarifica cum se manifestă variația sincronică și schimbarea autentică ce ține de dimensiunea „brahicronică”?

Mair (1994) a identificat cîteva întrebuințări ale verbului see 'a vedea' care ar putea, cu motivația de rigoare, fi considerate drept ipostaze de gramaticalizare timpurie. În Mair (1995) se argumentează că folosirea verbului help 'a ajuta' s-a schimbat rapid în engleza britanică din ultimii treizeci de ani. Nu e numai faptul că infinitivul zero s-a constituit în normă în Marea Britanie, ci și că frecvența generală a structurii help + infinitiv a crescut simțitor. Iată o versiune actualizată a tabelului din Mair (1995, p. 264):

\begin{tabular}{lcccc}
\hline & LOB A-C & FLOB A-C & Brown A-C & Frown $A-C$ \\
\hline 1. help + infinitiv zero & 4 & 21 & 9 & 36 \\
2. help + complement + infinitiv zero & 1 & 8 & 10 & 21 \\
3. help + infinitiv simplu & 14 & 6 & 5 & 7 \\
4. help + complement + infinitiv simplu & 3 & 7 & 4 & 2 \\
$\quad$ infinitiv zero: infinitiv simplu & 17 & $29: 13$ & $19: 9$ & $57: 9$ \\
total & $\mathbf{2 2}$ & $\mathbf{4 2}$ & $\mathbf{2 8}$ & $\mathbf{6 6}$ \\
\hline
\end{tabular}

Tabela 5: Uzul construcției help + infinitiv în patru corpusuri.

$\mathrm{Cu}$ ajutorul noilor date din corpusul Frown, ipoteza de plecare poate fi susţinută cu mai multă fermitate: anumite întrebuințări semi-idiomatice ale verbului help cu rol prepozițional (de ex., enunțul more money to help pay the bill $l^{\mathrm{f}}$, echivalent, în linii mari, cu more money for paying the bill ${ }^{\mathrm{g}}$ ) se gramaticalizează, punctul final al acestei evoluții fiind adăugarea unei prepoziții deverbale complexe în inventarul celor deja existente. Verificări de control în porțiunile de corpus rămase incomplete dezvăluie că schimbarea nu este specifică limbajului presei, posibilitatea fiind menţionată cu precauție în studiul iniţial (Mair, 1995, p. 270).

Este de așteptat ca, prin combinarea metodelor statistice cu cele de analiză textuală calitativă, cercetarea acestui fenomen și a altora de același fel constituie una din cele mai productive întrebuințări ale unor întregi corpusuri.

\footnotetext{
${ }^{3}$ Este adevărat că pentru studiul etapelor timpurii de gramaticalizare ar fi nevoie de cantități similare de material de limbă vorbită, iar acesta este, cu siguranță, un neajuns.

${ }^{\mathrm{f}}$ Mai mulți bani pentru a ajuta la plata facturii (n.tr.).

g Mai mulți bani pentru plata facturii (n.tr.).
} 


\section{5. „Colocvializarea” normelor în limba engleză scrisă}

Se pare că planul inițial de a studia schimbările în curs de realizare în limba engleză actuală a dezvăluit un ansamblu de fenomene sociolingvistice și discursiv-istorice, și anume „colocvializarea” în ultimii trezeci de ani a normelor limbii engleze scrise. Frecvența mărită a formelor de viitor continuu și de tip going-to, dispoziția crescîndă a celor ce scriu de a utiliza forme contrase precum și mutaţiile observate în alegerea structurilor genitivale inflexionale și perifrastice nu se datorează faptului că s-a schimbat gramatica limbii ca atare. Aceste tendințe sînt mai degrabă opțiuni informale care se află de multă vreme la dispoziția vorbitorilor și care sînt mai frecvent utilizate în prezent decît în urmă cu treizeci de ani.

Colocvializarea normelor uzului scris oglindită de corpusurile noastre paralele este corespondentul lingvistic al unei tendințe sociale generale, mai precis relaxarea manierelor și codurilor de conduită, fenomen pe care unii istorici și sociologici îl consideră tipic pentru societățile capitaliste dezvoltate, apărute după Cel de-al Doilea Război Mondial (vezi Hobsbawm, 1994, p. 331 și passim; Elias, 1989, p. 31158, despre „Civilizație și informalitate”; Featherstone, 1991, p. 45, 59-60). Protestele studențești de la sfîrșitul anilor 1960 și începutul anilor '70 sînt considerate momentele hotărîtoare în tranziţia dinspre societățile caracterizate de structuri instituționale formale, cu organizare ierarhică explicită și coduri rigide de etichetă spre societăți mai democratice - conform interpretărilor optimiste - sau spre camuflarea structurilor ierarhice existente prin promovarea egalitarismului și a unui cadru public informal (conform interpretărilor pesimiste). Din întîmplare, corpusurile LOB și Brown au fost compilate cu puțin înainte de revoluția culturală din 1968, iar după două decade au fost urmate de corpusurile noastre, astfel încît consecințele lingvistice ale perioadei sînt în mod fortuit suprinse în materialul cules.

Sociologii și istoricii interesaţi de procesul de informalitate sînt preocupați în special de aspectele socio-psihologice ale fenomenului. De pildă, Elias (1989) afirmă că, în ciuda așteptărilor cuiva, manierele mai relaxate de astăzi nu ar trebui interpretate ca o slăbire a controlului emoțional al indivizilor, ci ca o întărire, din moment ce numai un individ cu un control foarte bun poate face față opțiunilor multiple dintr-un climat social informal și destins ca cel din prezent. Normele exterioare impuse cu strictețe compensează slăbăciunile individuale, dar o puternică conștiință de sine este necesară pentru a supraviețui într-un mediu de anomie publică. Deoarece scopul lucrării de faţă nu este de a analiza asemenea incursiuni filosofice, revenim la consecințele pe care orientarea spre informalitate le are în istoria recentă a limbii. Elias însuși notează că schimbările din planul convențiilor comunicative ale unei societăți sînt indicii clare a ceea ce se petrece în adîncime. În Studien über die Deutschen [Studii asupra germanilor], el formulează multe comentarii relevante referitoare la diferitele maniere de adresare folosite de studenți și între studenți şi profesori în perioada Republicii de la Weimar și în primii ani ai Republicii Federale, pe de o parte, și în Germania contemporană, pe de altă parte (p. 329-360). În chip asemănător, Hobsbawm (1994) consideră că perioada anilor 1960 este marcată de „o turnură democratică în preferințele tinerilor occidentali de condiție superioară și medie” (p. 331), iar această afirmație corespunde tendințelor lingvistice observabile prin compararea corpusurilor paralele. Totodată, Hobsbawm subliniază și faptul că turnura democratică este un fenomen cu dublu tăiş. Pe de o parte, apare efectul de emancipare, iar acesta este un semn de interes şi de respect autentic față de modul de viață al claselor de mai jos. Pe de altă parte, fenomenul poate fi opresiv, în sensul recursului la elemente împrumutate din cultura marginală şi scoase din context, pentru a șoca elita fără a-i eroda poziția de putere.

În privința datelor descoperite în corpusuri ce ar putea fi spus mai mult decît că dezvoltarea de convenții stilistice este pe potriva dezvoltării societății în ansamblu şi că asupra acestui aspect se poate cădea cu ușurință de acord? Este oare posibil să descriem în mod mai sistematic interacțiunea dintre cele două tendințe? În acest cadru, contribuțiile lui Norman Fairclough și ale școlii de Analiză Critică a Discursului sînt de folos chiar și celor ce nu împărtățesc activismul politic de stînga al cercului.

Fairclough (1992) analizează „discursul și schimbarea socială în societatea contemporană” (acesta este 
titlul unui capitol din lucrarea sa, p. 200-224) . Autorul identifică trei mutații recente majore în cîmpul normelor comunicative, şi anume democratizarea, comodificarea și tehnologizarea discursului. Ultimele două tendințe nu fac obiectul preocupărilor din acest studiu, însă „informalitatea”, micșorarea distanței dintre normele vorbirii și cele ale scrierii, este considerată ca aspect al democratizării discursului. În termenii lui Fairclough, există manifestări corelate ale schimbărilor:

„în relaţiile dintre limbi și dialectele sociale, în accesul la tipurile de discurs cu prestigiu, în eliminarea mărcilor explicite de putere din discursurile instituționale bazate pe raporturi inegale de putere (...) și schimbări în practicile lingvistice ce țin de relațiile de gen.” (Fairclough, 1992, p. 201)

Prin recurs la o metaforă întrucîtva extravagantă, se consideră că discursul conversațional a „colonizat” atît domeniul mediatic cît și alte domenii în care era conservat specificul stilistic formal al scrisului:

„O dimensiune a manifestării informalității este răsturnarea raportului dintre discursul vorbit și cel scris. Am observat acest aspect în ziare (...), iar tendința către oralitate nu se manifestă doar în presa tipărită și în publicitate, ci și în specii discursive oficiale precum cererile de plată a drepturilor de asistență socială (...). Influenței scrisului asupra vorbirii pare să îi fi trecut vremea; valorile culturale contemporane pun mare preț pe informalitate, iar schimbarea predominantă este prezența oralității în scriere." (Fairclough, 1992, p. 204)

În calitate de activist social mereu atent, Fairclough încheie cu un avertisment: „rămîne de văzut în ce măsură informalitatea este simulată din rațiuni tactice; voi reveni asupra acestui aspect” (p. 205).

O problemă interesantă, în mod cert deschisă unei cercetări sistematice cu mijloacele lingvisticii corpusului, este relația dintre colocvialitatea scrisului și vorbire. Este adevărat că din ce în ce mai multe trăsături ale oralităţii pătrund în engleza scrisă, dar acesta este numai un aspect al problemei. Există o serie de trăsături lingvistice rare sau absente în vorbire, dar care sînt întrebuințate pentru a conferi informalitate textului scris, așa cum observă, de pildă, în apoziții ale grupului nominal avînd ca centru un nume de persoană, Labour Leader Tony Blair (în loc de Tony Blair, the Labour Leader) sau aging revolutionary leader Fidel Castro (în loc de Fidel Castro, the aging revolutionary leader ${ }^{\mathrm{h}}$ ), discutate de Jucker (1992). Colocvializarea normelor limbii engleze scrise este un fenomen care include două componente distincte, dar corelate: informalitatea autentică, adică transferul mai mult sau puțin conștient de elemente orale/conversaționale în scris, și anti-formalitatea, proces care poate fi definit drept recursul conștient la anumite mărci stilistice pentru a reduce gradul de formalitate al unui text ${ }^{5}$. În mod sigur, analiza colocvializării nu este ușurată de faptul că destul de adesea una și aceeași marcă lingvistică indică fie informalitatea, fie anti-formalitatea, în funcție de uzul ei involuntar sau ca figură retorică valorificată conștient.

În cartografierea aspectelor orale/conversaționale din limba scrisă ar fi interesant de observat dacă influența se produce în general sau dacă există puncte selective de pătrundere, precum citatele sau secvențele introductive și finale ale articolelor, elemente care au rolul foarte important de a stabili relația cu cititorul. În studiul său asupra contragerilor, Krug a pus în evidență recursul frecvent la ceea ce el a numit „,contrageri de rămas-bun”, arătînd, prin denumire, care este funcția lor. O privire mai atentă asupra materialului lingvistic din corpusuri permite și observarea faptului că înregistrarea unei creșteri accentuate

\footnotetext{
${ }^{4}$ Deși autorul își desfășoară activitatea în Lancaster, unul din punctele nodale ale lingvisticii corpusului, este interesant de observat că cercetările sale nu valorifică datele din corpusuri, însă aceasta este o constatare fără prea mare importanță în cadrul discuției noastre.

${ }^{\text {h} P r i n ~ a c t u l ~ d e ~ t r a d u c e r e, ~ a c e s t e ~ c o n s t r u c t ̦ i i ~ m a r c a t e ~ i n f o r m a l ~ a u ~ f o s t ~ n a t u r a l i z a t e ~ s ̦ i ~ i ̂ n ~ l i m b a ~ p r e s e i ~ r o m a ̂ n e s ̦ t i: ~ „ D u p a ̆ ~ z e c e ~}$ ani în fruntea guvernului britanic, liderul laburist Tony Blair își anunță săptămîna aceasta calendarul retragerii din funcțiile deținute” („Arena: Tony Blair își pregătește retragerea”, autor: Vlad Georgescu, 7 mai 2007, pagina în limba română a trustului BBC [online]); „Liderul revoluționar Fidel Castro a scris pe site-ul CubaDebate că «lumea se îndreaptă spre abis»” („Fidel Castro critică afirmațiile SUA pe tema scutului”, articol nesemnat, 7 ianuarie 2012, pagina ziarului Telegraf [online]) (n.tr.).

${ }^{5}$ Distincția stilistică între informal și anti-formal are ca fundament considerațiile lui Allsopp (1996).
} 
de uz a viitorului de tip going-to se datorează aproape în întregime prezenței în citări ale vorbirii directe: 51 din cele 67 de ocurențe din corpusul Frown sînt apariții în pasaje de vorbire directă, iar creșterea mai puțin semnificativă din FLOB poate fi interpretată în același fel.

\section{Concluzii}

Articolul prezintă cîteva din rezultatele deja obținute prin compararea corpusurilor LOB și Brown din 1961 cu FLOB și Frown, alcătuite în 1991/1992. Au fost observate foarte puține schimbări gramaticale reale. Majoritatea schimbărilor constatate poate fi interpretată ca urmare a colocvializării normelor limbii engleze scrise din ultimii treizeci de ani. Acest proces de colocvializare este corespondentul lingvistic al unei tendințe sociale generale de recurs insistent la elemente informale. În domeniul lingvisticii corpusului, lucrarea de față poate fi plasată în continuitatea foarte puținelor încercări de a valorifica corpusurile ICAME ca resurse pentru studiile culturale (cf. de ex. Hofland \& Johansson, 1982, Leech \& Fallon, $1992^{6}$, și, mai recent, Stubbs, 1996), iar dintr-o perspectivă lingvistică mai largă, sper că a fost pusă în lumină calea prin care studiile de lingvistică a corpusului pot contribui la dezvoltarea unui nou și important domeniu de cercetare interdisciplinară, și anume evoluția istorică a convențiilor discursive.

\section{Bibliografie}

Allsopp, R. (1996). Dictionary of Caribbean English usage, Oxford University Press.

Barber, Ch. (1964). Linguistic change in present-day English, Oliver and Boyd, London and Edinburgh.

Bauer, L. (1994). Watching English change: An introduction to the study of linguistic change in standard Englishes in the 20th century, Longman, London.

Biber, D., Finegan, E. \& Atkinson, D. (1994). ARCHER and its challenges: Compiling and exploring a representative corpus of historical English registers, în U. Fries, G. Tottie \& P. Schneider (eds), Creating and using English language corpora: Papers from the Fourteenth International Conference on English Language Research on Computerized Corpora, Zürich 1993, Rodopi, Amsterdam, p. 1-14.

Bloomfield, L. (1933). Language, Holt, Rinehart și Winston, New York.

Compes, I., Kutscher, S. \& Rudorf, C. (1993). Pfade der Grammatikalisierung: Ein systematisierter Überblick, Arbeitspapier 17, Institut für Sprachwissenschaft der Universität, Köln.

Elias, N. (1989). Studien über die Deutschen: Machtkämpfe und Habitusentwicklung im 19. und 20. Jabrhundert, editat de M. Schröter, Suhrkamp, Frankfurt.

Fairclough, N. (1992). Discourse and social change, Polity Press, Cambridge.

Featherstone, M. (1991). Consumer culture and postmodernism, Sage, London.

Gloderer, G. (1993). Morphological regularisation of irregular verbs: A comparison of British and American English, disertație masterală nepublicată, Freiburg.

Graf, D. (1996). Relative clauses in their discourse context: A corpus-based study, disertație masterală nepublicată, Freiburg.

Greenbaum, S. (1986). The Grammar of Contemporary English and The Comprehensive Grammar of the English Language, în G. Leitner (ed.), The English Reference Grammar, Niemeyer, Tübingen, p. 6-14.

Greenbaum, S. (1988). Good English and the grammarian, Longman, London.

Hobsbawm, E. (1994). Age of extremes: The short twentieth century 1914-1991, Michael Joseph, London.

Hofland, K. \& Johansson, S. (1982). Word frequencies in British and American English, Norwegian Computing Center for the Humanities, Bergen.

Holmes, J. (1994). Inferring language change from computer corpora: Some methodological problems, în „ICAME”, 18, p. 27-40.

Hundt, M. (1996). New Zealand English and its relation to British and American English: A corpus-based study in morphosyntactic variation, teză de doctorat, Freiburg.

Jespersen, O. (1909-1949). A modern English grammar on historical principles, 7 vol., Munksgaard, Copenhagen. Jucker, A. (1992). Social stylistics: Syntactic variation in British newspapers, Mouton de Gruyter, Berlin and New York, CrossRef.

\footnotetext{
${ }^{6}$ Studiul consemnează rezultatele unei analize comparative de conținut lexical din corpusurile Brown și LOB, sinteza de fond meritînd să fie amintită: „Însumînd constatările (...) într-o singură generalizare care ar putea părea exagerată, propunem un tablou al culturii Statelor Unite din 1961-masculină pînă la învecinarea cu machismul, militaristă, dinamică și animată de idealuri înalte, dirijată de tehnologie, implicare activă și liberă inițiativă—în contrast cu peisajul culturii britanice, mai predispusă la temporizare și dialog, beneficiară și nu creatoare de acumulări, mai aplecată spre viața de familie și cea emoțională, mai puțin interesată de chestiuni substanțiale și mai mult preocupată de reflectarea în plan exterior a propriului statut” (p. 4445).
} 
Krug, M. (1994). Contractions in spoken and written English: A corpus-based study of short-term developments since 1960, disertație masterală nepublicată, Exeter.

Lass, R. (1980). On explaining language change, Cambridge University Press.

Leech, G. \& Fallon, R. (1992). Computer corpora: What do they tell us about culture?, în „ICAME”, 16, p. 29-50.

Lehmann, C. (1991). Grammaticalization and related changes in contemporary German, în E. Closs Traugott \& B. Heine (eds), Approaches to grammaticalisation, vol. II, John Benjamins, Amsterdam, p. 493-535, CrossRef.

Lovejoy, J. (1995). Prepositions in British and American English: A computer-aided corpus study, în „Arbeiten aus Anglistik und Amerikanistik", 20, p. 55-74.

Mair, C. (1994). Is see becoming a conjunction? The study of grammaticalisation as a meeting ground for corpus linguistics and grammatical theory, în U. Fries, G. Tottie \& P. Schneider (eds), Creating and using English language corpora: Papers from the Fourteenth International Conference on English Language Research on Computerized Corpora, Zürich, 1993, Rodopi, Amsterdam, p. 127-137.

Mair, C. (1995). Changing patterns of complementation, and concomitant grammaticalisation, of the verb belp in present-day British English, în B. Aarts \& Ch. F. Meyer (eds), The verb in contemporary English: theory and description, Oxford University Press, p. 258-272.

Mair, C. \& Hundt, M. (1995). Why is the progressive becoming more frequent in English? - A corpus-based investigation of language change in progress, în „Zeitschrift für Anglistik und Amerikanistik”, 43, p. 111-122.

Olofsson, A. (1990). A participle caught in the act: On the prepositional use offollowing, în „Studia Neophilologica”, 62, p. 23-35, 129-149, CrossRef.

Potter, S. (1969), ediția a doua: 1975. Changing English, André Deutsch, London.

Raab-Fischer, R. (1995). Löst der Genitiv die Of-Phrase ab? Eine korpusgestützte Studie zum Sprachwandel im heutigen English, în „Zeitschrift für Anglistik und Amerikanistik”, 43, p. 123-132.

Sand, A. \& Siemund, R. (1992). LOB-30 years on ..., în „ICAME”, 16, p. 119-122.

Sand, A. (1996). Linguistic variation in Jamaica: A corpus-based analysis of radio and newspaper language, teză de doctorat, Freiburg.

Siemund, R. (1993). Aspects of language change in progress: A corpus-based study of British newspaper English in 1961 and 1991, disertație masterală nepublicată, Freiburg.

Siemund, R. (1995). For who the bell tolls: Why corpus linguistics should carry the bell in the study of language change in presentday English, în „Arbeiten aus Anglistik und Amerikanistik”, 20, p. 351-377.

Skandera, P. (1995). Computergestützte Korpuslinguistik und Sprachwandelforschung: Grammatische Neuerungen in der amerikanischen Pressesprache seit 1961, disertație masterală nepublicată, Freiburg.

Stubbs, M. (1996). Text and corpus analysis, Blackwell, Oxford.

[Traducere de Ioan Milică] 